\title{
The call and mission of the disciple in the Gospel according to Mark
}

\author{
Iulian Faraoanu \\ University "Alexandru loan Cuza", Iasi \\ Str. Vascauteanu 6, 700462 lasi, Romania \\ E-mail address: faraoanu@yahoo.com
}

Keywords: disciple, following of Jesus, call, mission, community, gospels.

\begin{abstract}
This paper is trying to focus on a few aspects on the figure of the Disciple of Christ in the Gospel of St. Mark. Since the beginning of his public activity, Jesus Christ wanted to be accompanied by disciples. They followed the Saviour and were witnesses to his wonderful words and deeds. After attending the school of Jesus, they were sent to continue the work of spreading God's Kingdom and the Gospel.

With respect to the presentation of the theme, after some general elements, we will analyse two texts from the Gospel: Mark 1:16-20 and Mark 3:13-19. These two fragments reflect an image of discipleship: the vocation, the conditions of the following, and the mission. To conclude, we present some theological reflections and an update at the beginning of this new millennium. Even for the present, it is important to do research in order to follow Jesus Christ as a disciple.
\end{abstract}

\section{Introduction}

The theme of this work is "The call and mission of the disciple in the Gospel according to Mark". The presentation is inspired by the Bible, the living and effective Word of God. At the same time, we consider the theme of faith.

As regards the "agenda" of the work, it could be structured as follows: we will first analyse two evangelical texts presenting a number of characteristics specific to the Disciples of Christ: the call and the mission. After having analysed each text, we will mention some theological and spiritual aspects and will attempt to do an update.

The noun disciple (the greek mathetes) is used around 294 times in the New Testament [1]. The Gospel refers either to the disciples of John the Baptist or of Jesus (sometimes to the disciples of the Pharisees (Matthew 22:15-16). In the synoptic gospels, the noun is used 73 times in Matthew, 46 times in Mark, and 37 times in Luke (and 78 times in John). In Luke, apart from the 12 apostles, there is the group of 70 disciples; starting with Acts 6, references to disciples comprise all who believe in Christ (Acts 9:10.26).

\section{Mark 1:16-20: THE CALL OF THE FIRST DISCIPLES}

The first text refers to the dimension of the call, inherent to discipleship. Many commentators have noted that Mark cannot perceive Jesus without the disciples. In fact, since the first public appearance of Jesus, the first gesture is to call a small number of disciples. As presented below, there are two accounts of the call, described using the same literary scheme.

\subsection{Structure of the text and literary scheme}
A. ${ }^{16}$ As Jesus walked beside the Sea of Galilee, he saw Simon and his brother Andrew,
B. casting a net into the lake, for they were fishermen.
C. "'Come, follow me," Jesus said, "and I will send you out to fish for people!"
B ${ }^{18}$ At once they left their nets,

A'. and followed him.

A. ${ }^{19}$ When he had gone a little farther, he saw James son of Zebedee and his brother John, 
B. in a boat, preparing their nets.

C. ${ }^{20}$ without delay he called them,

B'. and they left their father Zebedee in the boat with the hired men.

A'. and followed him.

The two accounts have the same literary scheme, comprising five points.

First, Jesus is described in movement (this being characteristic to the Gospel of Saint Mark): "walking along the sea"; "and going a little farther".

Second, Jesus is the one to have the initiative materialized in seeing: a penetrating glance, which captures the essential, namely the name of the person. He sees Simon and Andrew (they will be sent to proclaim the Gospel in groups of two), James and John. As noted, the person is seen in the real world it is part of, as family relationship (brother of ..., sons of ...) and social status are presented: their profession as fishermen and work.

Third, the glance becomes a call. Jesus calls in order to be followed.

Only the first account presents the words of the Master, while in the second account the words are implied. The call represents the centre of the text, not just at literary level (chiastic structure), but also with respect to the content.

The fourth element is represented by the prompt response of the ones being called (euthys), which is represented by the use of the verb "to leave". There is a crescendo: the first two leave their nets; then, the next ones called leave their father, the boat and the hired men.

The fifth and final element presents the result. The leaving is not an end in itself, but rather a functional action in view of following: disciples leave something to follow Jesus.

\subsection{The movement and the promise of Jesus}

Both accounts begin with a remark on "Jesus walking": he was walking beside the sea. There is no mention on the time, the distance; it is a symbolic passage valid to any time and space. In the Gospel of Saint Mark, it is important to emphasize the movement of Jesus. Almost every paragraph of the first two chapters begins with a motion verb "went", "came", "entered", "left", etc. These reveal the image of Jesus filled with divine pathos, in movement along people's routes. Mark can be defined "the gospel of the path": the path where Jesus walks and the path where he calls the ones who want to follow him. Even the phrase "follow me" suggests the image of the Saviour in movement [2].

The background is the "sea". Mark does not call it the Sea of Galilee but the Sea of Tiberias, as he is interested in the Galilee area, in contrast with Jerusalem. In fact, Jesus starts his public life in Galilee; this is also the place where the Disciples will start their mission after the Resurrection. This could be a symbolic reference to the Red Sea where the Israelites were saved, or may be a reference to the primordial waters of the beginnings of creation. Thus, Jesus' call would be a new exodus and a new creation.

The text continues with the annotation "he saw": Jesus' glance chooses them. It can even be a creative act [3]. This may be compared to the gesture of a mother who longs to see her newborn that will beers forever. God always looks to men with love and respect. In Jesus, we can see the divine glance; we see how God sees us. To see how God sees oneself means to discover the profound essence of one's own being that is the love the Lord shows oneself. Men feel called when, instead of running naked as Adam who perceived himself naked and judged, it sees how precious it is in God's eyes. Human happiness means to let oneself touched by this glance.

Furthermore, Jesus uses an imperative: "Follow me!"; he does not greet them or try to convince them to be his disciples, he does not propose programs. The call addressed by Jesus through his gesture, glance and word, refers to the result. Follow me (literally, behind me): thus, a call to follow a person, not necessarily a cause or doctrine. In fact, it is a communion of life with Christ.

A special attention is to be paid to the promise made to the first pair of brothers: "I will send you out to fish for people." What could such a promise mean? It probably underlines the reference to the former profession as basis for a new meaning. The metaphor was also known at Qumran: 
shepherds, nets and fish are realities perceived rather negatively, often referring to eschatological judgment (fish - outlaws at judgment; nets - chaos and death; fishermen - agents of eschatological judgment). A negative meaning can also be identified in Jeremiah 16:16 (a presentation of the judgment, with fishermen and hunters who will banish the people), and Ezekiel 29:4 (people trapped). However, this does not seem to be the meaning of the metaphor used by Jesus. If, on the one hand, in keeping with the biblical-Jewish background, the word could indicate crisis and judgment, on the other hand, in accordance with the gospel of the kingdom (1:14-15), it should indicate the gift of salvation. Thus, being sent out to fish for people, disciples must gather the people of Israel (proclaiming the Good News) and, after the resurrection, all the sons of God spread throughout the world [4]. A text to consider is Ezekiel 47:9-10. It is the famous episode of the water flowing from the right side of the Temple and into the Dead Sea, giving life to the salted waters. In those eschatological times, there will be a lot of fishermen on the shores of the Dead Sea, and their nets will be full of fish.

What does "being sent out to fish for people" mean? To fish for people could mean: to save people, to bring them back to life. More, to fish for people means to liberate people from evil forces, to call to conversion, faith, to lead them to the kingdom. Disciples must learn to fish for people, especially following the footsteps of Jesus and learning from him.

\subsection{The answer: to leave something in order to follow}

The answer given by Simon, Andrew, James and John (each called by name) is prompt, with no objection: they do not even say a word. They simply leave everything and follow Jesus. Why is that? Perhaps it is a normal reaction to the irresistible presence of God. Some people could ask: did the Disciples know anything about Jesus? Wouldn't it have been more appropriate to have a public appearance of Jesus, a preach followed by adherence to his doctrine? One explanation could be the inspiration in Elisha's call (and Elijah appears suddenly). Another explanation: the four Disciples have a special position in the group of twelve; from the very beginning, they witness everything Jesus says and does. Perhaps, in the early tradition, there was evidence that the ones called knew some things about Jesus and his teachings.

Another aspect is the fact that disciples are not called to learn something, but to follow. Their answer has the value of an example in the Gospel of Saint Mark: this is how everyone should answer. Therefore, the focus is not necessarily on the historical fact, but on the message Mark intends to convey to his community. Consequently, discipleship implies a definite answer: to leave everything and follow Christ. It is a free decision, the end of a lifestyle now belonging to the past.

The four persons called, already forming a community founded by Jesus, leave what, in those circumstances, was considered important for someone to be successful. They leave their nets, boat, the hired men and their father. We need to emphasize the crescendo of things left: first, the work tools (nets and boat), then the working environment - the social relations (the hired men), and, finally, their father, symbol of affective relationships and supreme figure in the patriarchal family context. The father was the one who had authority and represented family unity and work safety. Therefore, the father is more important than the boat or the nets. In the Old Testament there is the example of Elisha who gave up everything: his job, his work; moreover, he offers his possessions as sacrifice: he offers his oxen as sacrifice, and the yoke is used as firewood (see 1 Kings 19:21).

Thus, the things necessary for subsistence are of secondary importance. The only important and decisive reality is to follow Jesus [5]. Consequently, those who are called leave their profession (they were not practicing fishing as a sport, but as a profession) and their father. In brief, they leave the world they were living in. Peter later says: We have left everything to follow you! (10:28; according to Matthew 19:27-29). They only have a promise in front of them. The four disciples act similarly to Abraham who left his country believing in the divine promise. They accept to leave their world trusting only in the word of Jesus and heading towards the unknown. They leave everything and follow Christ unconditionally.

To conclude, there is a group of four people who entrust themselves and their future to the word of Jesus. They follow him on the path indicating that the time has come and the kingdom of God is 
near (they leave and follow the path of freedom, justice, love and life). Significantly, the next paragraph begins with the words "and entered into Capernaum." Jesus is no longer alone, being accompanied by the four disciples determined to follow him.

\subsection{Update: The call of the disciple nowadays}

The essential elements characterizing the call could be summarized in two components: 1) Jesus' movement and initiative, and 2) the answer.

With respect to this component, it is emphasized that Jesus moves on a permanent basis: he walks beside the sea, he goes a little farther, he hoes out again, etc. If Jesus is in constant motion, by antithesis, those called are inert: Levi, the tax collector, is sitting behind his desk; the sons of Zebedee are sitting in the boat: Simon and Andrew are sitting on the seashore.

Based on these observations, it is clear that the essence of the call addressed by Jesus to the future disciples lies in the invitation to take part in the movement, to join him. In other words, he invites the future disciples to leave their stable world and to embark on the journey, following the footsteps of Jesus. This is characteristic not only to Jesus' call, but to every call in the Bible, starting with the primary call of Abraham. He, too, was addressed with the words: "Go from your country!" Jesus' call is unexpected, surprising, while we are immersed in the rush of everyday life.

Any call begins with the interruption of the inertia, in order to embark on the journey towards something unknown, having as the only guidance the Lord's footsteps, his will which will somehow be revealed. Regarded from this perspective, the call is a personal experience inspired by the experiences of the chosen people: the flee from Egypt, an exodus from the stability and the security which were convenient to many, despite the inconveniences and the instability.

The analogy with the exodus can be taken a step forward. Similarly to the experience lived by the people of Israel, the ones called can also face moments when their fragile stability may seem better than the uncertain future of the Promised Land. Such a reaction is understandable from human perspective, yet contrary to the call. Therefore, from the very beginning, the ones called have to realize that, by accepting the call, they accept the movement, the change (not just the initial one); they accept a constant lifelong process of transformation. In the physical sphere there will always be new places to serve, new missions, new people we live and work with. However, the significant change should take place in our spiritual life. In this sector, as well, there is a risk of finding some stability, namely of creating a convenient image of a God who no longer asks anything from us or challenges us in any way, allowing us to live a life too quiet and peaceful. Therefore, in our spiritual life, too, we should be convinced that God is not a God of routine, but rather the God of the exodus. It is an exodus which implies risks and uncomfortable things (even the cross), but which leads to a life lived more and more in communion with the One who precedes us on the way.

The only person who acts in our text is the Lord: he is the one who moves, sees and speaks. The future disciples are only reacting, whereas the initiative belongs exclusively to Jesus. The fact that the initiative belongs totally to Jesus tells us that our life is only the acceptance of his words; it is nothing but a response.

There is another aspect to be pointed out. The initiative belongs to the Lord, and is not subject to any moral or intellectual level of the ones called. The text emphasizes certain aspects: the future pillars of the Church were fishermen, people who had nothing to do with the mission as spiritual leaders of God's people; they were not prepared for the upcoming mission. Therefore, according to Mark, the call does not take into consideration the intellect, the ethics of the candidates. Both will be required at a later stage; however, at the beginning, the call is accessible to all, no one is excluded. This contains a lesson of humility and gratitude. Nobody should imagine to have been chosen based on its extraordinary qualities that made Him choose us and not others. Instead, as he chose us, he could have chosen any other. He chose us as, in His power, he can bring to existence what does not exist, as Paul states in his Letter to the Romans: "God who calls is God who gives life to the dead and calls into being that which does not exist" (Romans 4:17). In 1Corinthians 1:2629: "Consider your own call, brothers and sisters: not many of you were wise by human standards, 
not many were powerful, not many were of noble birth. But God chose what is foolish in the world to shame the wise; God chose what is weak in the world to shame the strong..."

Our call should remind us of a truth that we are often tempted to forget: God chooses certain people in his service not because they are meritorious, capable and worthy. The very fact of being elected, by grace because He loves them, this is what makes them worthy of the love and correspond to the entrusted mission. We received everything for free, so all we have to do is show humility and gratitude.

A further annotation: in most religions, men seek God. In Christianity, however, God seeks men. His proposal is direct and personal: he himself, due to his love, asks me to follow him; in turn, the answer must be direct and personal.

There are many books on the "essence of Christianity". Mark summarizes this in two words: "Follow me!", the result being something personal and dynamic, in the footsteps of the Master. The entire Gospel shows Jesus walking, and disciples must follow his footsteps. Jesus is not only a model to be imitated or the one who leads the way, he is also a companion on the journey.

At the end, we can notice that the fragment presents the elements of faith. Faith involves activation of all our sensory, intellectual and moral abilities. Jesus passes looking for us, he sees us and calls us; we see, hear, understand and respond to the call, leaving everything and following his footsteps. The Christian faith means in fact following the Lord; it is a pair of legs to follow Jesus, as we have been conquered by him, the absolute love which is worth more than anything.

Later on, his question and our answer are the two constituents of faith, both direct and impossible to be assigned. No one can be called for me and no one can answer on my behalf. The others can help, can be intercessors; however, faith cannot imply intermediaries; it is a direct report between me and him. Therefore, it is necessary not to accept Christianity as an ideology, as this would be an attack to faith. Faith is not to believe that there is a God; it is the relationship with Jesus, my Lord. Faith is a relationship with him, a mutual belonging based on love [6].

\section{Mark 3:13-19: The Forming of the Group of Disciples (the mission)}

The account has the following stages: a) the call and the answer (verse 13); b) the appointment of the group of twelve, giving them the name as apostles, and explanation of the purpose of the call (verses 14-15); c) the list of the twelve apostles (verses 16-19). The first call was addressed to the disciples to follow him; the second call implies a qualitative progress: to be with Jesus, to be his friends.

\subsection{The call in the mountains}

Jesus leaves the places where he was surrounded by the crowds and by the disciples and climbs the mountains. The allusion to the mountains is not meant to indicate a certain mountain; the mention of the set has, in fact, a theological significance: the mountains are a place of isolation from people, and closeness to God (in other texts of Mark the mountains are a secluded place, ideal for prayer $-6: 46$, or a set for theophany reserved only to certain disciples $-9: 2.9$ ). The mountains remind of the epiphany and the alliance (Mount Sinai where God gives the Law, Exodus 19:3 and the following). In this context, from 3:13-19, the mountains are the place where Jesus reigns and, in a sovereign manner, calls those he chooses (the crucifixion will be in the mountains, as well, on the Calvary).

When getting away from the noise of the world (the separation from others and the climbing of the mountains gives authority to what is about to happen), in order to directly address God, Jesus wants to be joined by those he wanted. Calling them and separating them from the crowds (in fact they are separated from the crowds and take a step forward), Jesus is selecting his permanent audience with whom he will have a profound relationship.

The verb "to call" expresses a relation of superiority and dependence between the subject and the object: Jesus calls the twelve with authority, in his capacity as their Lord. 
The mention "those he wanted" complements and specifies the call (it is worth mentioning that there is no indication of the qualities of the ones called). With a certain emphasis, it is mentioned that the ones called were wanted and personally chosen by Jesus (the verb "like" corresponds to a Hebrew verb meaning "to care about someone", "to be fond to someone"; it seems to be an expression of affection, a predilection of the heart towards these persons; they were called because they were loved). The tense used (which indicates a continuous action) expresses lasting desire, continued over time. It is a sovereign act, full of authority, but not a spontaneous one. Jesus' personal initiative is part of a plan long thought of and prepared.

Mark indicates then the answer of the ones called "and they came to him": it is not mentioned that they obeyed and accepted the invitation, they just "went to him"; Mark uses a simple and clear language. Later on, there is a fourth mention, since the beginning of the gospel $(1: 18.20 ; 2: 14)$, on the positive attitude of the interlocutors with respect to Jesus' initiative. At the same time, there is an emphasis on the extraordinary effectiveness of Jesus' words, which accomplish what it is said.

In Greek, the phrase "and they came to him" does not indicate only the movement towards Jesus, but also the separation of the ones called from the crowds (they leave the place where they were, see aperchomai). This separation can also be understood from symbolic perspective: it is reflected in the change of mentality and of life. The proximity of Jesus is another sign of the action of following the Master who becomes the ultimate reference point for them.

\subsection{The appointment of the twelve and purposes of the group (verses 14-15)}

After the answer of the twelve, Mark inserts some basic provisions on their power and authority.

The first decision regards the number of recipients "and appointed twelve". The verb poieo ("made - constituted") presents Jesus' gesture in its entirety. Subsequently, this verb expresses the effort to make them "fish for people". The use of the verb describes the act of the sovereign will of Jesus, given that in LXX it is frequently associated to God and has the characteristic of appointment (YHWH created his people; however, reference is more often made to the appointment of priests or of other ministries, see 1Samuel 12:6; 1Kings 12:31).

The undetermined form of the phrase, "to appoint twelve", refers to the initial act of the appointment of the twelve: it is the beginning of the existence of a specific group, distinct from the other disciples. The text does not explicitly indicate a relationship between the twelve and the twelve tribes of Israel, as in Matthew 19:28 and Luke 22:30.45. Therefore, in Mark, the centre of gravity of the action of "appointing twelve" seems to depend more on the person and authority of Jesus, than on the allusions in the Old Testament. However, we should also consider the idea on God's people with the twelve tribes (the twelve apostles are the pillars and the foundation of the spiritual edifice of the Church).

Next, Mark indicates the second decision of Jesus: giving them the name as "apostles". The text seems to be intended to describe the future mission of the entire group and to indicate the power that Jesus has on the ones called who are given a new name, a name that expresses their total dedication to him (see 6:7.12). The verb "appointed" associated with "called" describes the global character of the action performed by Jesus who, by virtue of his authority, related them to his person and makes them his companions and messengers with full power.

Mark describes Jesus' third decision relating to the mission of the apostles: "that they might be with him" (14c), which is in fact the first goal of his intervention. The phrase introduced by "that" with the meaning of a final outcome, reveals Jesus' intention to have total and permanent communion. Solemnly called as a group, they are invited to live with him, to join him in his mission (3:14 to $6: 6 ; 6: 6 b-8: 26)$ and, consequently, to ensure a close relationship among them. For Mark, the expression "be with him" $(4: 36 ; 5: 18 ; 14: 67)$ has the meaning of communion with Jesus and strengthens the sense of adherence to him. In fact, they should depend on Jesus, and this is a sign of maturity.

The force of the tense used "that they might be with him" expresses Jesus' will to have them with him. Staying united to him, the twelve can then be sent out as his messengers (6:7.12). Therefore, to be called companions of Jesus means that he can be the main reference point; in the 
meantime, staying with the others acquires significance, as well. Therefore, the vital centre of Christian discipleship and the source of its power lie in the personal relationship with the Master (to be with him also means to follow him on the way of the cross). The most significant aspect for Mark is: the disciples are Jesus' companions and live in his presence, in a close relationship with him and in an on-going learning process.

The second purpose of the call is: "that he might send them out to preach and to have authority to drive out demons", thus specifying what it means to be an apostle (6:7.12). Compared to the initial imperative "Follow me and I will send you out to fish!" (1:17), this description of the disciples' work is explained and shows Jesus' intention to really make them fish for people; therefore, they take part in the mission of proclaiming the Good News and are given the power to drive out demons, thus favouring the establishment of God's kingdom (the driving out of demons was a sign of replacement the dominion of the Evil with the kingdom of God).

The twelve, together with the essential requirement on the vital communion with Jesus as companions, are also entrusted the task to act as his agents. Starting with this moment, they will live in intimate communion with Jesus, having the position as heralds of the Gospel and the legal capacity to drive out demons (power understood not necessarily at physical level, but as authority received from Jesus; using this power, they can fight the forces of evil and extend the establishment of the kingdom). Compared to the initial call (1:17), the metaphor "I will make you fish for people" (1:17) is developed within the account by means of a specific plan and a specific program (see 1:16$20,3: 14-15 ; 6: 7.12-13$ ). Before being sent to fish, the twelve will have to complete a long learning program with Jesus; however, it is obvious that, after resurrection, they are the ones that will be able to communicate the apostolic experiences lived in communion with Jesus.

\subsection{The list of the twelve names (verses 16-19)}

In biblical language, the names in the Old Testament express the very identity of the person, identity that is manifested to others. God is the only one who can change the name; a change of name is like a new beginning, a new birth, a new identity, and a new mission.

The composition of the list, the order of the names and the additions made to certain names are particularly interesting. As acknowledged, the lists of Matthew and Luke do not correspond entirely to that of Mark, as the former present personal touches.

Not only does Mark (similarly to the other evangelists) put Simon at the top of the list, not only does he highlight (more than the other evangelists) the symbolic addition of the name "Peter", but he separates this disciple from his brother Andrew and curiously he associates him to the two sons of Zebedee, John and James. The three will be then privileged witnesses to some events: the raising of Jairus' daughter (5:37); the Transfiguration (9:2), and the agony in the Garden of Gethsemane (14:33). When reflecting on the relation connecting these events, we realize that by means of these events, the three disciples are trained to be able to perceive in a more special manner the mystery of the person of Jesus and his divinity, despite his human actions; moreover, they need to be able to understand the path that passes through the cross, in order to present all this to the future Christian community (the three seem to be separated from the group of twelve: their names are changed; they take part in the main events of the Jesus' revelation; in Galatians 2:9, they are the pillars of the church in Jerusalem).

Mark is the only one to say in this passage that Jesus called the two sons of Zebedee "the sons of thunder", an expression difficult to clarify (the name comes from Aramaic; probably, the two disciples were unknown to Mark's community). It is probably that the name does not necessarily refer to their impetuous nature (see Luke 9:54), but contains, as in the case of Peter (the rock), a prophecy: they will be exposed to the eschatological challenges; they will participate in the baptism of the death of the Lord (10:38-40). His companions will have to endure the wars and the persecutions of the eschatological era.

After these disciples who are given special names, the list continues with the names of the others (the presentation of the names could be the reflex of Jesus' calling them by name), and, in the end, Judas Iscariot (Iscariot: perfid man; another explanation ish Kerioth: a man of Kerioth), with 
the terrifying annotation present in all the Gospels and in the early Church, "who later betrayed him" (paradidomi: handed him). In the "Son of man" theology, developed more in the Gospel of St. Mark, this expression is quite heavy. His being part of the group of twelve apostles chosen by Jesus himself remains a mystery (14:18: one of you shall betray me). Discipleship is Jesus' initiative par excellence (God's love is true and immutable, whereas man is changeable). The call represents an act of his utter domination which is not dependent on any special status of the possible candidates or of the person called; however, the answer to the call is dependent on human freedom, thus making failure possible.

Mark emphasizes the forming of the group of apostles (but does not then describe their being sent on mission, as does Matthew). The forming of the group has two purposes: for them to be with Jesus, and then to be sent on mission [7].

\subsection{Update: the mission of the disciple nowadays}

The mentioned texts on the call clearly indicate that the initiative comes exclusively from Jesus. The text in Mark 3:13-20 strongly indicate this aspect. Mark first emphasizes this by the mention "he wanted", thus focusing on the Jesus' will and his total freedom. Later on, the verb used by Mark, compared to other positive verbs expressing the will, has a meaning close to the idea of "whim", arbitrary choice. Thus, one might refer to the call-mission as a whim of divinity, provided it remembers as follows: God's whims are always out of love.

A specific aspect relating to Mark's text is the thorough presentation of the duties of the ones called. Until now, everything could be reduced to a command: "Follow me!" With respect to the appointment of the twelve, this "Follow me!" contains three specific actions. Indeed, he appoints the twelve so that they: a) might be with him (the dimension of faith as personal relationship with Jesus); b) might be sent out (the dimension of the action) to preach; c) have authority to drive out demons. These three elements indicate the purpose of calling of the twelve and, to a certain extent, describe the mission. Spontaneously, we believe that they were sent to preach and work miracles, but the first item of the program is as follows: he appointed the twelve so that they might be with him. The Christian life, in general, and religious life, in particular, as well as the opposition or alternative between contemplation or activity, prayer or discipleship, are often discussed upon, and it is suggested that these would be in competition. Mark does not accept such opposition. Being with Jesus is the first aspect of the mission. Furthermore, being with Him is indicated not only as a requirement for the success of the mission, but as mission in itself; it could also be the main purpose of the mission, as it is indicated first on the list. Union with Jesus is the cause, purpose and the manner of the mission. Being with him is the first aspect of our discipleship (nobody gives what they do not have!); the rest comes only after: to preach and to drive out demons.

Regarding the two latter aspects, it is necessary to mention an important detail: according to Mark, the only thing that Jesus did up to that moment was to preach and to drive out demons, nothing else. Thus, all three purposes of the mission are reduced to one: a close relationship with the Master that will be visible either by physically being with him or in the action indicating Jesus' way of acting (preaching and driving out demons). Jesus must become the point of reference for those he calls, this being reflected either in their way of being or in their manner of acting. This is their call and their mission.

Another aspect: the two moments (being with Jesus and the action) must coexist, but not become one. If they do not coexist, there is either the risk of falling in an abstract faith or the risk of activism, of blind and cold efficiency. This is a signal for today's Church: either a faith detached from the real problems or an efficient activism without faith; faith and deeds must coexist.

An additional analysis in relation to "being with Jesus": this is the purpose of our life and mission; it is the essence of each son. To be a disciple means to be with Jesus: it is the identity, a life union, a mission and destiny union. In addition, it is a remedy for solitude, as disciples are with the Lord who keeps them company and which is in relationship with them [8].

The purpose of following Jesus is to be with him forever (1Thessalonians 4:17) because he is my life (Philippians 1:21). With him, I am myself, beloved son of the Father who loves us with a 
unique, full and complete love. This way, Christianity is not an ideology: it is real companionship with Jesus, in a personal relationship, involving all our senses and capabilities; it is the choice to live for Jesus and to live as he lived.

First of all, we "are with him" with open ears to listen to his word; then, with open eyes to see his face. This desire to listen to him and contemplate him is the faith which opens our heart to him. It is materialized in reading the Word and in prayer, docility and worship.

Furthermore, we "are with him" using our feet in order to follow him on the same path. This desire to walk as he walked is the hope that touches our life to make it similar to his. It makes us prefer and choose what he preferred and chose, to be closer to him and to resemble him to the greatest extent possible. This loving hope frees the heart from any attachment to evil and determines us to love poverty and humility out of love for him.

Finally, we "are with him" using our hands to touch him and be in full communion with him. This desire to touch him is the love which makes us identify in him and render our life similar to his, causing us to love and act like him. In order to be with him, he himself heals our ears, eyes, hands and feet.

More than a final destination, being with him is a permanent starting point for a closer and true following. St. Paul says: "Not that I have already obtained this or am already perfect, but I press on to make it my own, because Christ Jesus has made me his own." (Philippians 3:12) Being with him is to be conquered by him, to be in love with him, with the desire that makes our life a unique invocation: "Maranatha! Come Lord Jesus!"

\section{Conclusion}

Having reached the end, we can draw some conclusions. First, we can say that the Bible presents disciples as the ones called. Jesus, who has the initiative, sees them (lovingly looks at them) and addresses the call. This call is addressed in the actual life environment. What kind of call is there nowadays? The call to decision, determination, despite routine and habit. Then, the call to courage to overcome ideas on fashion and adjustment to the everyday lifestyle.

Disciples must answer in a prompt manner, without hesitation, without having any requests. Moreover, they need to leave everything (Philippians 3:3-11).

With regard to the identity, the disciple has a personal relationship with the Master. A true disciple imitates the Master. And the first activity of the disciples is to be together with Christ. It is not about sitting next to Christ, it is a matter of being with Christ. The main characteristic of the mission is the fact of being sent to preach and be witnesses through deeds [9].

With respect to the obligations, the first duty of the disciples is to know Christ.

As regards the mission of the disciples, their first activity is to be with Christ. The focus is not on physical presence, but rather on being, therefore a matter of participation.

The second element of the mission is the sending of the disciples to preach and to give testimony by their deeds.

Such disciples realize that they are not superior to their master and follow the Master with fidelity and love, in a radical manner. At the same time, they live their life conscious of the need of permanent conversion, in faith and hope.

\section{References}

[1] F. W. Danker (ed.), A Greek-English Lexicon of the New Testament and other Early Christian Literature, Chicago and London, 2000, 609.

[2] E. Best, Disciples and Discipleship. Studies in the Gospel of St. Mark, Edinburgh 1986.

[3] K. Stock, Marco, Commento testuale al secondo Vangelo, Edizioni ADP, Roma 2003, 37.

[4] J. Gnilka, Marco, Cittadella Editrice, Assisi 1987, 86. 
[5] L. Di Pinto, Seguitemi, vi faro diventare pescatori de uomini!, Parola, Spirito e vita, 2 (1980) 101.

[6] S. Fausti, Ricorda e racconta il vangelo, Ancora, Milan 1998, 38.

[7] I. Faraoanu, Isus Cristos in evangheliile sinoptice, Sapientia, Iasi 2014.

[8] A. Spreafico, Marco. Il primo Vangelo, Urbaniana University Press, Roma 2000, 61-62.

[9] I. Faraoanu, Some Aspects of the Disciple's figure in the Gospel according to Matthew", International Multidisciplinary Scientific Conference on Social Sciences and Arts, SGEM 2015, 26 aug -01 sept 2015 Albena Bulgaria, Book 3 Anthropology, Archaeology, History and Philosophy, 131-139. 